\title{
Use of probiotics in diets of wild-type chickens and its effects on performance
}

\section{Uso de probiótico em dietas de frangos tipo caipira e seus efeitos sobre o desempenho}

\author{
VALENTIM, Jean Kaique ${ }^{1 *}$; PAULA, Karynne Luana Chaves de ${ }^{1}$; GERALDO, \\ Adriano $^{2}$; MIRANDA, Diogo Alvarenga ${ }^{2}$; LEMKE, Sara Santana Ramos ${ }^{2}$; OLIVEIRA, \\ Marllon José Karpeggiane de ${ }^{3}$; OLIVEIRA, Jeferson Éder Ferreira de ${ }^{1}$
}

\author{
${ }^{1}$ Universidade Federal dos Vales do Jequitinhonha e Mucuri, Departamento de Zootecnia, Diamantina, \\ Minas Gerais, Brasil. \\ ${ }^{2}$ Instituto Federal de Minas Gerais, Bambuí, Minas Gerais, Brasil. \\ 3Universidade Estadual Paulista, Departamento de Zootecnia, Jaboticabal, São Paulo, Brasil. \\ *Endereço para correspondência: Kaique.tim@hotmail.com
}

\section{SUMMARY}

The objective of this study was to evaluate the performance of male colonial chickens fed diet supplemented with commercial probiotic (Calsporin ${ }^{\circledR}$ ). A total of 210 male chicks Label Rouge lineage were used and they were raised in experimental shed up to 30 days old. These birds had free access to the pickets of Tifton-85, from 31-90 days of age. The experimental design was completely randomized, two treatments, one containing feed supplemented with probiotic Bacillus subtillis (300 $\mathrm{g} \mathrm{t}^{-1}$ Bacillus subtillis $1 \times 10^{9}$ $\mathrm{UFCg}^{-1}$ ) and another one without it, with ten replications per treatment, consisting of 21 chickens/replication. The mean of body weight (BW), weight gain (WG), feed intake (FI), feed conversion (FC), mortality and viability were evaluated. The data were submitted to variance analysis and the averages of the treatments were compared by the F-test at $5 \%$ of significance. The addition of probiotic (300 $\mathrm{g} \mathrm{t}^{-1}$ Bacillus subtillis $\left.1 \times 10^{9} \mathrm{UFCg}^{-1}\right)$ in the diet of Label Rouge broilers did not interfere in the $\mathrm{MW}, \mathrm{WG}$, and $\mathrm{FC}$ variables in the total period from 1 to 90 days $(\mathrm{P}>0.05)$; the MFI variable differed $(\mathrm{P}<0.05)$, with higher consumption in chickens receiving the diet with the probiotic. The inclusion of probiotic in the wild-type chicken ration did not improve the productive performance of poultries possibly due to a low challenge by pathogenic microorganisms in the environments in which they were raised.

Keywords: alternative breeding, bacillus subtillis, peeled neck, wild-type chickens

\section{RESUMO}

Objetivou-se com este estudo avaliar o desempenho de frangos coloniais machos alimentados com ração suplementada com probiótico comercial (Calsporin ${ }^{\circledR}$ ). Foram utilizados 210 pintos de corte machos da linhagem Label Rouge, e foram criados em galpão experimental até os 30 dias de idade. Estas aves tiveram livre acesso aos piquetes de Tifton-85 (Cynodon spp.) dos 31 aos 90 dias de idade. O delineamento experimental utilizado foi inteiramente casualizado, dois tratamentos, um contendo ração suplementada com probiótico Bacillus subtillis (300 $\mathrm{g} \mathrm{t}^{-1}$ Bacillus subtillis $1 \times 10^{9}$ $\mathrm{UFCg}^{-1}$ ) e outro sem suplementação, com dez repetições cada, constando 21 aves/repetição. Foram avaliados o peso corporal médio (PM), ganho de peso (GP), consumo de ração (CR), conversão alimentar (CA), mortalidade e viabilidade. Os dados foram submetidos à análise de variância, e as médias dos tratamentos foram comparadas pelo teste $\mathrm{F}$ a $5 \%$ de significância. A adição do probiótico (300 $\mathrm{g} \mathrm{t}^{-1}$ Bacillus subtillis $\left.1 \times 10^{9} \mathrm{UFCg}^{-1}\right)$ na dieta de frangos Label Rouge não interferiu nas variáveis GP, PM, e CA no período total de 1 a 90 dias $(\mathrm{P}>0,05)$; a variável CMR diferiu $(\mathrm{P}<0,05)$, sendo maior o consumo em aves recebendo a dieta com o probiótico. A inclusão de probiótico na ração de frangos caipiras não melhorou o desempenho produtivo das aves possivelmente devido a um baixo desafio por microorganismos patogênicos nos ambientes em que foram criados.

Palavras-chave: aves caipira, Bacillus subtillis, criação alternativa, pescoço pelado 


\section{INTRODUCTION}

The production of wild-type birds is an activity which market is very promising, since the supply of this product is lower than the demand (SANTOS et al., 2010), besides the commercialization that can be carried out directly, from producer to consumers, making the products prices viable and attractive.

According to the regulation $\mathrm{n}^{\circ} 64$ from MAPA (2008), chickens raised in the free-range system must respect the minimum time for slaughter of 85 days and it is prohibited the use of growth promoters based on antibiotics in the feed.

An alternative to the restriction of antibiotics is the use of probiotics, which are food supplements based on living microorganisms that beneficially affect the host animal, improving the intestinal microbial balance (FULLER, 1989), and consequently protect the digestive system providing a better use of food. The use of probiotic provides an intestinal colonization by a beneficial microflora and there is a preservation of intestinal villi integrity, improving the digestion and absorption of nutrients and, consequently, the performance.

The use of probiotics, until now, is very contradictory because of the results obtained, which part of these researches indicates efficiency, and the other does not. There are few studies evaluating the feed supplementation for the colonial strain (wild-type) with probiotics that associate the type of grass of the paddock area and alternative foods used.

Based on this survey, the objective of this study was to evaluate the effectiveness of probiotic feed supplementation based on Bacillus subtillis (300 $\mathrm{g} \mathrm{t}^{-1}$ Bacillus subtillis $1 \times 10^{9}$ $\mathrm{UFCg}^{-1}$ ) and its action on the productive performance of male colonial chickens of the Label Rouge lineage.

\section{MATERIAL AND METHODS}

The experiment was carried out at the Federal Institute of Minas Gerais Bambuí Campus, from January to March, 2016. A total of 210 day-old male broiler chicks Label Rouge strain (peeled neck) were used. Chicks were vaccinated in the hatchery against Marek's disease.

The project was approved by the UNIFENAS Ethics Committee on Animal Use (CEUA), filed under number 13A/2015.

A completely randomized design was used, with 2 treatments (feed supplemented with $300 \mathrm{~g} \mathrm{t}^{-1}$ with commercial probiotic (Calsporin $($ ) and feed without supplementation) and 5 replications with 21 birds each. The supplemented probiotic was based on Bacillus subtillis $\left(1 \times 10^{9} \mathrm{UFCg}^{-1}\right) \mathrm{DSM}$ $15.544(30 \%)$ and Calcium Carbonate $(70 \%)$. Dietary treatments were provided to birds from the day 1 to 90 days of age. The birds were raised in the first 30 days in a conventional experimental shed for broiler chickens and they were vaccinated at 21 days old according the vaccination program proposed by the Colonial Line Handling Manual (GLOBO AVES, 2015).

The experimental shed consists of 24 plots with individual area of 2.16 square meters. 21 chicks of one-day old were selected and weighed and putted in each plot with data computation for a control of the birds average weight per plot.

Ten plots were used on the east side of the shed, with an empty plot, without animals, between the plots to avoid contamination with Bacillus subtillis. This shed went through a period of 15 
days of sanitary emptiness, dry cleaning, wet cleaning with the use of detergent in the water, rinsing and disinfection with the use of quaternary ammonia at a concentration of $10 \%$.

The shed was equipped with external curtains system on the sides with mechanical ratchet type activation, positive pressure ventilation system and fogging system for temperature and internal humidity control. The density used in the plots until 30 days old was $9.72 \mathrm{birds} / \mathrm{m}^{2}$. The heating system was powered by infrared lamps of $250 \mathrm{~W}$ potency, individually installed in each experimental plot, and central lighting system with automatic turning on through a timer.

The light program used was natural light after 15 days old, before this age these lamps were lit at night and there was continuous emission of light, making up 24 hours of illumination. The substrate used for the bed was crushed rice husk that was reused only once in a commercial batch of broiler chickens.

For the preparation of the bed for reuse, the feathers were burned and the stick parts were removed, not using a fermentation process by windrowing, only bagging for transportation and to use in the research.

The water supply to the birds in the plots occurred via a pendulum tanker and the feed was supplied in infant tubular feeders until the seventh day, with the installation of the adult tubular feeders after this day. Feeding was done twice a day and bed turnover was done daily. Feeding of birds from each treatment was done only by one person to avoid cross-contamination between plots from the beginning to the end of the research.

At 30 days old, the birds were transferred to the experimental paddocks, each one with a total area of $77.35 \mathrm{~m}^{2}$, including the area for mobile shelter covered with raffia canvas and $10 \mathrm{~m}^{2}$ floor area and were installed a pendulum tanker, an adult tubular feeder, a roost and the forage used was Tifton - 85. The recommendation of MAPA (Circular Letter No. 4, 1998) was observed, with a minimum supply of $3 \mathrm{~m}^{2}$ of paddock area per bird from 30 to 90 days old, disregarding the shelter area.

From the total of 20 paddocks, only 10 were used for experimental plots in order to keep the birds receiving the treatment with the probiotic without contact with the birds of the control treatment, to avoid cross contamination, since the used additive was easily disseminated in the environment, through the ration.

The maximum and minimum temperatures of the shed and paddocks were checked twice a day, using a maximum and minimum thermometer at the height of the animal and annotated to calculate the final average in the evaluation period.

Experimental diets were based on corn and soybean meal and formulated to meet nutritional recommendations according to the Colonial Line Handling Manual (GLOBO AVES, 2015). It was used the diet program with four diets, being distributed in the forms of initial ration (1 to 29 days), growth I (30 to 49 days), growth II (50 to 79 days) and finishing (final - 80 to 90 days). All the diets, according to the raising phase, were isoenergetic, isoproteic, isoaminoacidic, isocalcic, and isophosphoric, as shown on Table 1.

The feed was offered to poultries ad libitum. The rations were provided in the form of meal and free of growth promoters, anticoccidials and ingredients of animal origin. The variables of productive performance evaluated were:

- Mean weight gain per bird (WG) and mean body weight (BW): the mean weight gain and mean body weight of birds were evaluated in two phases: up to the growth phase I (from one day to 
30 days), and up to the final phase (from one day to 90 days).

In the period from 1 to 30 days, the birds were weighed in a Toledo, Model: 9094 scale with a capacity of $15 \mathrm{~kg}$, and, for the other days (31 to 90), it was used an electronic scale Filizola Star $150 \mathrm{~kg}$, model: $78624,150 \mathrm{~kg}$, to calculate the gain and average weight of the birds.

Table 1. Experimental ingredient composition of country-type Peeled Neck male chicken at different production phases (1 to 29,30 to 49,50 to 80 and 81 to 90 days of age), supplemented with or without Bacillus subtillis probiotic.

\begin{tabular}{|c|c|c|c|c|c|c|c|c|}
\hline Ingredient (kg) & $\begin{array}{l}C^{*} \\
1-29\end{array}$ & $\begin{array}{l}\mathrm{P} * * \\
1-29\end{array}$ & $\begin{array}{c}C^{*} \\
30-49\end{array}$ & $\begin{array}{c}\mathrm{P}^{* *} \\
30-49\end{array}$ & $\begin{array}{c}C^{*} \\
50-80\end{array}$ & $\begin{array}{c}\mathrm{P}^{* *} \\
50-80\end{array}$ & $\begin{array}{c}C^{*} . \\
81-90\end{array}$ & $\begin{array}{c}\mathrm{P}^{* *} \\
81-90\end{array}$ \\
\hline Corn grain $7 \%$ & 63,85 & 63,85 & 65,94 & 65,94 & 69,24 & 69,24 & 71,25 & 71,25 \\
\hline $\begin{array}{l}\text { Soybean meal } \\
46 \%\end{array}$ & 31,90 & 31,90 & 29,50 & 29,50 & 25,60 & 25,60 & 24,10 & 24,10 \\
\hline Soybean oil & - & - & 0,50 & 0,50 & 1,40 & 1,40 & 1,60 & 1,60 \\
\hline Calcareous & 1,50 & 1,50 & 1,50 & 1,50 & 1,30 & 1,30 & 0,95 & 0,95 \\
\hline Common salt & 0,40 & 0,40 & 0,40 & 0,40 & 0,40 & 0,40 & 0,40 & 0,40 \\
\hline $\begin{array}{l}\text { Dicalcium } \\
\text { phosphate }\end{array}$ & 1,85 & 1,85 & 1,70 & 1,70 & 1,60 & 1,60 & 1,35 & 1,35 \\
\hline Probiotic $^{1}$ & - & 0,03 & - & 0,03 & - & 0,03 & - & 0,03 \\
\hline Kaolin & 0,03 & - & 0,03 & - & 0,03 & - & 0,03 & - \\
\hline DL-Methionine & 0,22 & 0,22 & 0,21 & 0,21 & 0,21 & 0,21 & 0,13 & 0,13 \\
\hline Choline $60 \%$ & 0,05 & 0,05 & 0,04 & 0,04 & 0,04 & 0,04 & 0,03 & 0,03 \\
\hline Vitamin Premix ${ }^{2}$ & 0,10 & 0,10 & 0,10 & 0,10 & 0,10 & 0,10 & 0,10 & 0,10 \\
\hline Mineral Premix ${ }^{3}$ & 0,10 & 0,10 & 0,08 & 0,08 & 0,08 & 0,08 & 0,06 & 0,06 \\
\hline Total: & 100 & 100 & 100 & 100 & 100 & 100 & 100 & 100 \\
\hline \multicolumn{9}{|c|}{ 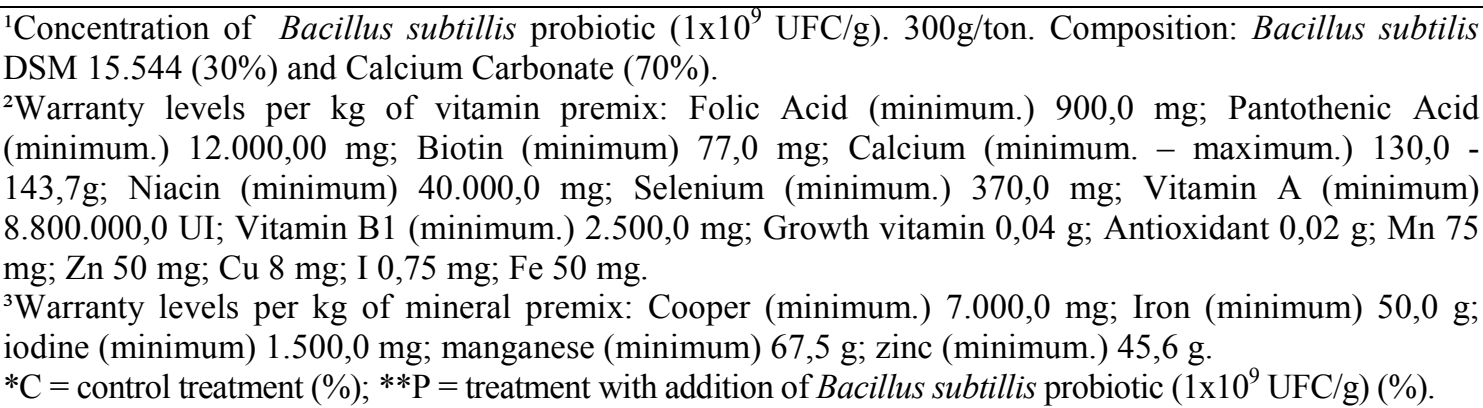 } \\
\hline
\end{tabular}

- Average feed intake (FI): the average feed intake was determined by dividing the difference between the feed provided during the phase per treatment and the weighted leftover feed at the end of the phase by the number of birds in the plot. The averages were totaled to result in the average feed intake per bird in the plot. - Feed conversion (FC) by bird: the feed conversion was calculated by dividing the average feed intake by the average weight gain of the birds of the studied plots.

- Mortality (M): mortality was monitored daily for the correction of consumption and feed conversion, considering the weighing of the leftover ration on the day of mortality, according to the methodology described by Sakomura \& Rostagno (2007).

- Viability: the viability analysis was calculated using the formula: Viability = (100) - (\% of mortality). 


\section{RESULTS AND DISCUSSION}

The minimum and maximum temperature averages of the initial 30day life period of the animals housed in the shed, and the 60 days of breeding in the paddocks were 21 and $30^{\circ} \mathrm{C}$ and 19 and $29^{\circ} \mathrm{C}$, respectively.
The averages of the performance variables (average feed intake, weight gain, feed conversion (FI/BW and FI/WG) and mean broiler weight in the period from 1 to 30 days did not show significant differences $(\mathrm{P}>0.05)$ among the analyzed treatments (table 2).

Table 2. Performance of male broilers of Label Rouge lineage fed with diets supplemented with (PRO) or without $(\mathrm{C})$ probiotic in the periods from 1 to 7 and 1 to 21 days of age

\begin{tabular}{lcccccc}
\hline \multirow{2}{*}{ Variables } & \multicolumn{3}{c}{$1-7$ Days } & \multicolumn{3}{c}{$1-21$ Days } \\
\cline { 2 - 7 } & $\mathrm{C}^{1}$ & $\mathrm{PRO}^{2}$ & $\mathrm{CV}^{3}$ & $\mathrm{C}^{1}$ & $\mathrm{PRO}^{2}$ & $\mathrm{CV}^{3}$ \\
\hline $\mathrm{CMR}(\mathrm{kg})$ & 1.22 & 1.19 & 9.44 & 1.09 & 1.09 & 5.98 \\
$\mathrm{GP}(\mathrm{kg})$ & 010 & 0.10 & 3.81 & 0.52 & 0.54 & 3.04 \\
$\mathrm{CA}(\mathrm{CR} / \mathrm{GP})(\mathrm{kg} / \mathrm{kg})$ & 2.04 & 2.00 & 9.85 & 1.99 & 11.99 & 5.54 \\
$\mathrm{CA}(\mathrm{CR} / \mathrm{PM})$ & 1.51 & 1.42 & 9.42 & 1.86 & 1.89 & 6.02 \\
$\mathrm{PM}(\mathrm{kg})$ & 0.14 & 0.13 & 2.04 & 0.57 & 0.57 & 2.58 \\
\hline
\end{tabular}

*Averages of the treatments in the study period differ statistically by the F test $(\mathrm{P}<0.05)$

${ }^{1}$ Control diet without addition of probiótico; ${ }^{2}$ Diet with addition of Probiotic Bacillus subtle DSM 15,544 $\left(1 \times 10{ }^{9} \mathrm{CFU} / \mathrm{g}\right) 300 \mathrm{~g} / \mathrm{ton} ;{ }^{3} \mathrm{CV}=$ coefficient of variation $(\%)$.

According to Gonzales (2004), the benefits of using probiotics are higher in contaminated or challenged environments, high densities and for animals with low resistance to diseases, which is not included in this study, because it was used a lineage with higher rusticity when compared to industrial broilers, an adequate density according to legislation requirements and low challenge. This fact may be related to biosecurity in breeding, cleaning of installations, plant health and a possible low concentration of pathogens in the reused bed used in this study.

Corrêa et al. (2003), in testing different probiotics in diets for broiler chickens, observed a lower feed intake in the group that received probiotic than in the control group during the period of 0-21 days old.

Others authors have studied many products combining with probiotics to substitute antibiobitcs. Rocha et al. (2010) concluded that mannan-oligosaccharides, whether or not combined with fumaric and propionic organic acids, and probiotics may substitute the antibiotics avilamycin and colistin in broiler diets without performance loss.

The results of this research are different from those found by Boratto et al. (2004) who concluded that the use of antibiotic and probiotic increased the weight gain of the birds in the period from 1 to 21 days old, in which birds treated with antibiotic presented better feed efficiency, and Zulkifli et al. (2000), who observed greater weight gain in the group treated with probiotic in relation to the control group without antibiotic, but with weight gain similar to the group of birds that received feed with antibiotic.

Lima et al. (2003) studying the inclusion of probiotic, verified that there was no significant effect on the performance of the birds. These authors observed that 
treatments with probiotics (Calsporin 10, Finelact), prebiotic (Lactifit, regardless of the evaluated characteristic - weight gain, feed intake or conversion - or food combination), did not have statistical differences between those of both products, for broiler chickens up to 21 days old.

Opalinsk et al. (2007), in a study with probiotic (Bacillus subtillis) in diets for broiler chickens, verified that the use of probiotic got better results only for birds feed conversion, in the period from 1 to 21 days old.

Regarding the performance of the animals in the period from 1 to 90 days old, it shows that the average feed intake variable had significant differences, presenting a higher consumption in birds receiving the treatment with addition of probiotic in relation to the control diet (Table 3).

Table 3. Performance of male broilers of Label Rouge lineage fed with diets supplemented with (PRO) or without (C) probiotic in the periods from 1 to 30 and 1 to 90 days of age

\begin{tabular}{lcccccc}
\hline \multirow{2}{*}{ Variables } & \multicolumn{3}{c}{$1-30$ days } & \multicolumn{3}{c}{$1-90$ days } \\
\cline { 2 - 7 } & $\mathrm{C}^{1}$ & $\mathrm{PRO}^{2}$ & $\mathrm{CV}^{3}$ & $\mathrm{C}$ & $\mathrm{PRO}^{2}$ & $\mathrm{CV}^{3}$ \\
\hline FI $(\mathrm{kg})^{*}$ & 1.717 & 1.822 & 6.11 & $10.544^{*}$ & $10.94^{*}$ & 1.52 \\
WG $(\mathrm{kg})$ & 0.910 & 0.920 & 2.48 & 3.582 & 3.703 & 2.84 \\
FC $(\mathrm{CR} / \mathrm{WG})(\mathrm{kg} / \mathrm{kg})$ & 1.887 & 1.981 & 6.36 & 2.944 & 2.955 & 2.86 \\
FC $(\mathrm{CR} / \mathrm{BW})$ & 1.810 & 1.920 & 7.02 & 2.913 & 2.930 & 2.70 \\
BW $(\mathrm{kg})$ & 0.949 & 0.949 & 2.15 & 3.621 & 3.734 & 2.67 \\
Viability $(\%)$ & - & - & - & 99.04 & 96.19 & 4.08 \\
\hline
\end{tabular}

*Averages of treatments on the line within the study period statistically differ by the $\mathrm{F}$ test $(\mathrm{P}<0.05)$.

${ }^{1}$ Control diet without addition of probiótico; ${ }^{2}$ Diet with addition of $300 \mathrm{~g} \mathrm{t}^{-1}$ of probiotic based on Bacillus subtillis DSM $15.544\left(1 \times 10^{9} \mathrm{UFC}^{-1}\right){ }^{3} \mathrm{CV}=$ coefficient of variation $(\%)$.

The other performance variables did not present significant differences among the studied treatments. The nonoccurrence of a significant difference in the other variables of weight gain and feed conversion may be due to the fact that the experiment was performed providing feed at all breeding stages, and this supply met the requirements of birds that have a limit of performance improvements.

Flemming \& Freitas (2005) observed that the addition of probiotic, associated or not to prebiotic, did not generate a significant difference $(\mathrm{P}>0.05)$ in broilers performance, coinciding with the present study.
These authors report that the best results of weight gain and feed conversion, presented by the probiotic compared to the control and antibiotic groups in the initial phase of life, suggest a better balance between the probiotic microorganisms (Bacillus licheniformis and Bacillus subtillis), desirable eutrophic flora and undesirable residual flora.

Pelícia et al. (2004) did not find improvement in productive performance by the use of probiotics, prebiotics or yeasts, when used in the ration until the 84 days of life in broilers. However, Santin et al. (2001) described beneficial effects by the use of probiotics in broiler diets when attributing these effects to the eutrophic action of probiotics and 
prebiotics on microorganisms of the gastrointestinal system.

Godoi et al. (2008), who used diets supplemented with antibiotic, symbiotic (Bacillus licheniformis, Bacillus subtillis) or mannan-oligosaccharides in diets for broiler chickens from 1 to 42 days old, observed that they improved birds performance.

Jin et al. (1998), in a study with broiler chickens to investigate the effect of a mixture of Lactobacillus on the birds performance breed in hot temperature $\left(30.1^{\circ} \mathrm{C}\right.$ average) and high relative humidity of $95 \%$ (conditions considered to be stressful for birds), showed greater efficiency in relation to control birds, both in weight gain and feed conversion, when Lactobacillus were added.

The absence of probiotic effect may be related to the sanitary conditions, because, without pathogenic bacteria for a challenge, the probiotic cannot perform competitive exclusion. In the present research, the animals were raised in paddocks never used for the breeding of any other animal, thus avoiding any type of pathogenic action, which diminished the challenge faced by the chickens.

The presence of sanitary challenge situations, as well as any stress situation and the relationship between the number and type of viable microorganisms present in the probiotic, may be related to the efficiency of this product (LIMA et al., 2003).

The broiler chicks were raised since the first day in reused beds, to subject them to a higher sanitary challenge, since, according to Andreatti (2006), the restoration of the intestinal microbiota balance of the animal is the main beneficial effect of the use of probiotics.

However, this factor may not have contributed to the increase of the sanitary challenge, mainly related to intestinal health, since the reused bed underwent all the appropriate disinfection procedures, which may have eliminated most of the pathogenic microorganisms. The breeding conditions can directly influence the efficiency of the growth promoting additives (BORATO et al., 2004).

The mortality rate observed during the whole experimental period was $2.4 \%$, considering the whole batch - optimum values compared to the industrial breeding, which, to be considered good, should be up to $3 \%$.

As probiotic efficacy is very dependent on these factors (sanitary challenge, animal type, etc.) it is difficult to compare the different studies (BORATTO et al., 2004; LODDI et al., 2000), besides the great diversity of probiotic, forms of supply and experimental conditions adopted in the various studies (BORATTO et al., 2004). Thus, it can be said that the sanitary challenge was not sufficient to demonstrate the effectiveness of the probiotic used.

The inclusion of $300 \mathrm{~g} \mathrm{t}^{-1}$ of Bacillus subtilis DSM 15.544 probiotic in the Label Rouge broiler diet did not influence birds' performance in the evaluated period. It is presumed that the sanitary challenge was not sufficient to demonstrate the efficacy of the probiotic.

\section{REFERENCES}

ANDREATTI FILHO, R. L. Saúde aviária e doenças. São Paulo: Roca, 2006. 314p.

BORATTO, A.J.; LOPES, D.C.; OLIVEIRA, R.F.M.; ALBINO, L.F.T.; SÁ, L.M.; OLIVEIRA, G. A.Uso de antibiótico, de probiótico e de homeopatia em frangos de corte criados em ambiente de conforto, inoculados ou não com Escherichia coli. Revista

Brasileira de Zootecnia, v.33, n.6, p.1477-1485, 2004. 
CORRÊA, G.S.S.; GOMES, A.V.C.; CORRÊA, A.B.; SALLES, A.S.;

MATTOS, E.S. Efeitos de antibióticos e probióticos sobre o desempenho e rendimento de carcaça de frangos de corte. Arquivos Brasileiros de Medicina Veterinária e Zootecnia, v.55, n.4, p.2332, 2003.

FLEMMING, J.S.; FREITAS, R.J.S. Avaliação do efeito de prebióticos (MOS), probióticos (Bacillus licheniformis e Bacillus subtilis) e promotor de crescimento na alimentação de frangos de corte. Archives of Veterinary Science, v.10, n.2, p.41-47, 2005.

\section{GLOBO AVES. Manual de manejo}

Linha Colonial. Cascavel: Globo Aves Agropecuária Ltda., 2015. 24p.

GODOI, M.J.D.S.; ALBINO, L.F.T.U.; ROSTAGNO, H.S.U.; GOMES, P.C.U.; BARRETO, S.L.D.T.U.; VARGAS JUNIOR, J.G.D.U. Utilização de aditivos em rações formuladas com milho normal e de baixa qualidade para frangos de corte. Revista Brasileira de Zootecnia, v.37, n.6, p.1005-1011, 2008.

GONZALES, E. Ação pró-nutritiva dos aditivos alimentares. Curso de fisiologia da digestão e metabolismo dos nutrientes em aves. Jaboticabal, SP: Universidade Estadual Paulista, 2004.

FULLER, AFRC, R. Probiotics in man and animals. Journal of Applied Bacteriology, v.66, n. 5, p. 365-378, 1989.

JIN, L.Z.; HO, Y.W.; ABDULLAH, N.; ALI, M.A.; JALALUDIN, S. Effects of adherent Lactobacillus cultures on growth, weight of organs and intestinal microflora and volatile fatty acids in broilers. Animal and Feed Science Technology, v.70, n.3, p.197-209, 1998.
LIMA, A.C.F.D.; PIZAURO JÚNIOR, J.M.; MACARI, M.; MALHEIROS, E.B. Efeito do uso de probiótico sobre o desempenho e atividade de enzimas digestivas de frangos de corte. Revista Brasileira de Zootecnia, v.32, n.1, p.200-207, 2003.

LODDI, M.M.; GONZALES, E.; TAKITA, T.S.; MENDES, A.A.; ROÇA, R.D.O. Uso de probiótico e antibiótico sobre o desempenho, o rendimento e a qualidade de carcaça de frangos de corte. Revista Brasileira de Zootecnia, v.29, n.4, p.1124-1131, 2000.

MAPA. Ministério da Agricultura e do Abastecimento. Instrução Normativa $\mathrm{n}^{\circ}$ 64 de 18 de dezembro de 2008. Dispõe sobre normas para regulamento técnico de sistemas orgânicos de produção animal e vegetal. Diário Oficial [da] República Federativa do Brasil, Brasília, DF, 2008.

OPALINSK, M.; MAIORKA, A.; DAHLKE, F.; CUNHA, F.; VARGAS, F.S.C.; CARDOZO, E. On the use of a probiotic (Bacillus subtilis - DSM 17299) growth promoter in broiler diets. Revista Brasileira Ciência Avícola, v.9, n.2, p.99-103, 2007.

PELÍCIA, K.; MENDES, A.A.; SALDANHA, E.S.P.B.; PIZZOLANTE, C.C.; TAKAHASHI, S.E.; MOREIRA, J.; KOMIYAMA, C.M. Use of prebiotics and probiotics of bacterial and yeast origin for free-range broiler chickens. Revista Brasileira de Ciência Avícola, v.6, n.3, p.163-169, 2004.

ROCHA, A.P.; ABREU, R.D.; COSTA, M.D.C.da; OLIVEIRA, G.J.C.de; ALBINATI, R.C.B.; PAZ, A.S.da; PEDREIRA, T.M. Prebióticos, ácidos orgânicos e probióticos em rações para frangos de corte. Revista Brasileira de Saúde e Produção Animal [online], v.11, n.3, p.134-143, 2010. 
SANTIN, E.; MAIORKA, A.;

MACARI, M.; GRECCO, M.;

SANCHEZ, J.C.; OKADA, T.M.;

MYASAKA, A.M. Performance and

intestinal mucosa development of

broiler chickens fed diets containing

Saccharomyces cerevisae cell wall.

Journal of Applied Poultry Research, v.10, n.10, p.236-244. 2001.

SANTOS, M.J.; PANDORFI, H.;

ALMEIDA, G.L.; MORRIL, W.B.;

PEDROSA, E.M.; GUISELINI, C.

Comportamento bioclimático de frangos

de corte caipira em piquetes

enriquecidos. Revista Brasileira de

Engenharia Agrícola e Ambiental,

v.14, n.5, p.554-560, 2010.

SAKOMURA, N.K.; ROSTAGNO,

H.S. Métodos de pesquisa em

nutrição de monogástricos.

Jaboticabal: FUNEP, 283p. 2007.

ZULKIFLI, I.; ABDULLAH, N.;

AZRIN, N.M.; HO, Y.W. Growth

performance and immune response of

two commercial broiler strains fed diets

containing Lactobacillus culture and

oxy tetracycline under heat stress

conditions. British Poultry Science,

v.41, n.5, p.593-597, 2000.

Receipt date: $22 / 02 / 2018$

Approval date: 22/06/2018 